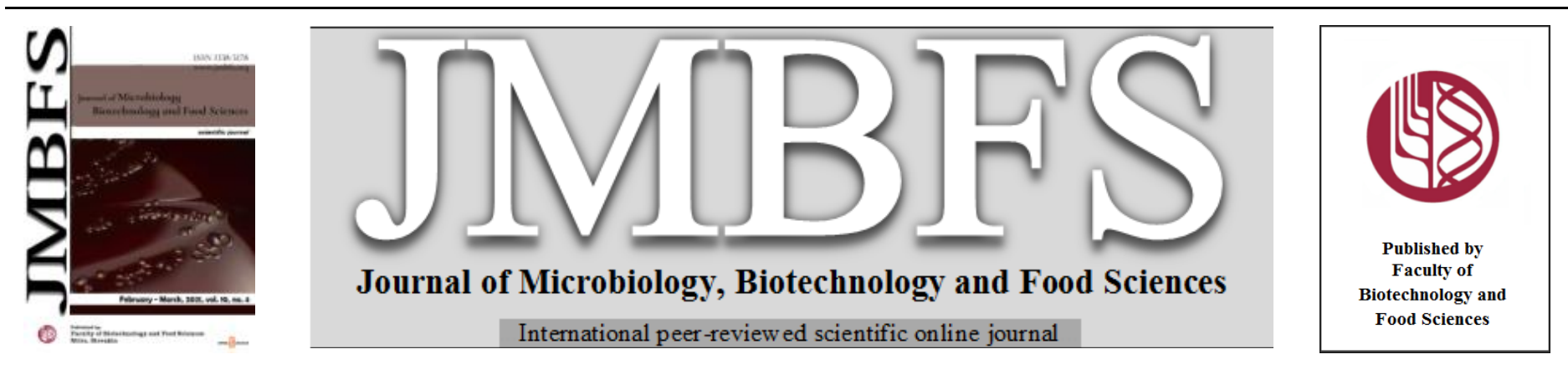

\title{
IDENTIFICATION OF STAPHYLOCOCCUS SPP. ISOLATED FROM FOOD BY TWO METHODS
}

\author{
Ivana Regecová $*^{I}$, Jana Výrostková ${ }^{2}$, František Zigo, ${ }^{3}$ Monika Pipová ${ }^{1}$, Pavlina Jevinová ${ }^{1}$, Soňa Demjanová ${ }^{1}$
}

Address(es): MVDr. Ivana Regecová, PhD.,

${ }^{1}$ University of Veterinary Medicine and Pharmacy, Department of Food Hygiene and Technology, Institute of Meat Hygiene and Technology, Komenského 73, 041 81 Košice, Slovak Republic.

${ }^{2}$ University of Veterinary Medicine and Pharmacy, Department of Food Hygiene and Technology, Institute of Milk Hygiene and Technology, Komenského 73, 04181 Košice, Slovak Republic.

${ }^{3}$ University of Veterinary Medicine and Pharmacy, Department of Nutrition, Dietetics and Animal Breeding, Institute of Animal Breeding, Komenského 73, 041 81 Košice, Slovak Republic.

*Corresponding author: ivana.regecova@uvlf.sk

doi: 10.15414/jmbfs.2021.10.4.546-552

ARTICLE INFO

Received 11. 5. 2020

Revised 25. 9. 2020

Accepted 2. 10. 2020

Published 1. 2. 2021

Regular article

open $\partial_{\text {ACCESS }}$

\begin{abstract}
One hundred and ninety-three staphylococcal strains were isolated from samples of alaska pollock meat (Theragra chalcogramma), atlantic mackerel meat (Scomber scombrus), atlantic herring meat (Clupea harengus), and femoral muscle samples of the wild pheasants (Phasianus colchicus), wild rabbits (Oryctolagus cuniculus) and bryndza cheese. Phenotypic manifestations typical of individual staphylococcal species were detected in these isolates. Species identification was also performed by matrix-assisted-laserdesorption-ionization-mass-spectrometry on the basis of which 5 species of staphylococci were determined: S. aureus, S. epidermidis, $S$. capitis, S. haemolyticus, S. warneri. Subsequently, the presence of the $16 \mathrm{~S} r D N A$ gene was confirmed by PCR assay; a specific sequence for $S$. aureus species; putative transcriptional regulator gene serp0107, a specific sequence of the sodA gene was used to identify $S$. epidermidis and to identify $S$. warneri, S. haemolyticus, S. capitis species. When comparing the results of identification by PCR assay and matrix-assisted-laser-desorption-ionization-mass-spectrometry, the identification at the genus level was identical in all cases $(100 \%)$. However, the discrepancies in results were confirmed at the species level, where congruence for identification of isolates by PCR assay and matrix-assisted-laser-desorption-ionization-mass-spectrometry was only $80 \%$. For these isolates, the score value ranged from 1.953 to 2.564 .
\end{abstract}

Keywords: MALDI-TOF-MS, meat, PCR, bryndza cheese, staphylococci

\section{INTRODUCTION}

Staphylococci often occur in food samples, whether as a desirable or contaminating microflora (Iacumin et al., 2006; Martín et al., 2006). In particular, the group of coagulase-negative staphylococci (CoNS) includes some species that have GRAS status (generally considered safe). These types of staphylococci are involved in the development of the organoleptic features of the final products. Some CoNSs are used as starter cultures to produce dry fermented sausage and cheese due to their aromatic and pigmentary abilities (Corbière Morot-Bizot et al., 2007). Although CoNS is generally considered to be a bacterium that has a positive role in the production of some fermented foods (Irlinger, 2008), the identification of certain risk factors in CoNS strains, as well as the existence of nosocomial and urinary tract infections related to Staphylococcus epidermidis and Staphylococcus saprophyticus, raised questions regarding the presumption of safety of species belonging to this group (Zell $\boldsymbol{e t}$ al., 2008).

Von Eiff et al. (2006) suggest that the occurrence and pathogenic potential of some CoNS species may correspond to emerging pathogen in food. The identified risk factors correspond to virulence factors (Zell et al., 2008), antibiotic resistance (Regecová et al., 2014), the ability to produce biogenic amines (Martín et al., 2006) and biofilm formation on the surface of equipment used in the food industry (Silva et al., 2017). Among the potential pathogens of the genus Staphylococcus spp. we classify mainly Staphylococcus epidermidis, Staphylococcus capitis, Staphylococcus haemolyticus and Staphylococcus warneri, which inhabit human skin. Although infection with these staphylococci is rare compared to Staphylococcus aureus, at endangered hosts, the risk of developing staphylococcal infection increases (Stollberger et al., 2006).

At the same time, it is generally accepted that the food chain has been recognized as one of the major routes of transmission of potential pathogens as well as antibiotic-resistant bacteria between the human and animal populations. Staphylococci, belonging to this group of bacteria, can be present in many different types of additives used in the food industry due to their high resistance and multi-application ability (Pesavento et al., 2014). The identification and differentiation of food-related staphylococci is essential to ensure quality and is the basis for ensuring the availability of safe and healthy food for consumers (Drozenová and Petráš, 2000; Wenning et al., 2014).

Traditional methods used to identify and classify bacteria, which are based on the analysis of morphological, physiological and biochemical traits or genetic approaches (DNA-DNA or RNA-DNA hybridization, determination of $\mathrm{G}+\mathrm{C}$ content in DNA), are currently supplemented by sequence analysis of small subunits of rRNA by PCR methods (Bencúrová et al., 2013). However, it is necessary to shorten the analysis time, in the species identification of microorganisms (including bacteria of the genus Staphylococcus spp.) without any former knowledge of genetic targets.

One such method is matrix-assisted laser desorption ionization time-of-flightmass-spectrometry (MALDI-TOF-MS). Over the last few years, MALDI-TOFMS tools for microbiological identification of potential pathogens and foodborne pathogens have been improved. These commercial, easy-to-use MALDI-TOFMS devices contain their own algorithms and databases. Many studies report fast, cost-effective, and accurate performance of MALDI-TOF-MS systems (Clark $\boldsymbol{e} t$ al., 2013; Croxatto et al., 2012). However, data for comparison among commercial MALDI-TOF-MS devices are limited, especially for Gram-positive cocci isolated from food (Deak et al., 2015).

Therefore, the aim of this study is to identify selected species of the genus Staphylococcus spp. based on phenotypic expression and PCR to be used as common methods for the identification of staphylococci. At the same time, the MALDI-TOF-MS method is used to identify food isolates of staphylococci. However, the accuracy of this method may vary compared to the identification of clinical isolates of staphylococci identified by this method in clinical studies. 


\section{MATERIAL AND METHODS}

\section{Sampling}

Individual strains were isolated from 5 samples of alaska pollock meat (Theragra chalcogramma) originating in FAO fishing zone 61 (China), 5 samples of atlantic mackerel meat (Scomber scombrus) originating in FAO 27 fishing zone (Ireland), 5 samples of atlantic herring meat (Clupea harengus) fishing effor originating in FAO 27 fishing zone (Norway), from 3 samples of the thigh muscle of the wild pheasants (Phasianus colchicus), 4 samples of wild rabbits (Oryctolagus cuniculus) originating from a hunt in the region of East Slovakia and 6 samples from meat of carcasses of chickens after combined cooling in a local poultry slaughterhouse. Strains were also isolated from 3 samples of bryndza cheese from purchased in the regular shopping branch. Sampling, preparation of test samples, initial suspensions and decimal dilutions for microbiological examination were carried out according to the requirements of ISO 6887-2 (2017), ISO 6887-3 (2017) and ISO 6887-5 (2020).

\section{Isolation of strains and detection of their phenotypic features}

Staphylococci were isolated from food samples according to ISO 6888-1/A1 (2003) and subsequently staphylococcal colonies from the surface of agar medium by Baird-Parker (OXOID, Hampshire, UK) were individually inoculated on the surface of Columbia blood agar and after 24 hours incubation at $37^{\circ} \mathrm{C}$, the presence and type of hemolysis as well as the formation of yellow pigment were evaluated. They were then inoculated from blood agar into test tubes with $3 \mathrm{ml}$ of Brain Heart Infusion Broth (BHI broth; OXOID, Hampsire, UK).

After 18-24 hours of incubation at $37^{\circ} \mathrm{C}, 0.1 \mathrm{ml}$ of the multiplied broth culture of the test strains was added to $1 \mathrm{ml}$ of reconstituted freeze-dried rabbit plasma in a test tube (Staphylo PK test, IMUNA, Šarišské Michal'any, SR). The inoculated plasma was incubated at $37^{\circ} \mathrm{C}$. Formation of coagulum was considered as positive reaction. Results were read after 1, 2, 3, 6 and 24 hours. Each isolate propagated in BHI broth was also inoculated onto the surface of DNase agar (OXOID, Hampsire, UK) containing DNA. DNase-producing colonies hydrolyzed the DNA contained in the agar. After 24 hours of incubation at $37^{\circ} \mathrm{C}$, the surface of the medium was flooded and acidified with $1 \mathrm{~N}$ hydrochloric acid, the DNAprecipitated, the medium became clear zones appeared around DNasepositive colonies.

Isolated strains were also tested for resistance to novobiocin, which is one of the factors dividing CoNS into two groups. $0.1 \mathrm{ml}$ of a 24 -hour bacterial suspension of the tested strains of staphylococci in BHI broth, adjusted to the 0.5 McFarland turbidity standard was inoculated onto the surface of the Müller-Hinton agar (OXOID, Hampsire, UK). Subsequently, commercially produced standard disks with a novobiocin concentration of $30 \mu \mathrm{g}$. disk ${ }^{-1}$ were applied to the agar surface using a dispenser (OXOID, Hampsire, UK). No later than 15 minutes after disk application, the plates were placed in thermostats and incubated at $37^{\circ} \mathrm{C}$ for 24 hours. After 24 hours of incubation, the diameters of the inhibition zones (including the disc) in millimeters were measured using a calibrated measuring instrument. The results were evaluated according to the criteria set by the Becton Dickinson \& Comp (1996).

Matrix-assisted-laser-desorption-ionization-mass-spectrometry TOF-MS)

(MALDI-

The extraction procedure using ethanol and formic acid was used to prepare the samples for MALDI-TOF-MS identification. Two full loops of bacterial cells containing $1 \mu \mathrm{l}$ were resuspended in an test tube with $300 \mu \mathrm{l}$ of distilled water. $900 \mu \mathrm{l}$ of absolute ethanol was mixed into the test tube and the mixture was centrifuged $(15000 \mathrm{rpm} / 2 \mathrm{~min})$. The supernatant was pipetted off $50 \mu 1$ of $70 \%$ formic acid and $50 \mu \mathrm{l}$ of acetonitrile were added to the pellet before analysis and the mixed mixture was centrifuged again $(15000 \mathrm{rpm} / 2 \mathrm{~min})$

Subsequently, $1.0 \mu \mathrm{l}$ of supernatant was applied to a MALDI plate, which, after drying, was overlaid with $1.0 \mu \mathrm{l}$ of a saturated solution of $\alpha$-cyano-4hydroxycinnamic acid (HCCA) in $50 \%$ acetonitrile and $2.5 \%$ trifluoroacetic acid (Bruker Daltonics, 2008). The analysis of the results was performed in an Ultraflex III device. The obtained results were processed using Flex Analysis software, version 3.0 and evaluated using BioTyper software, version 1.1 (BRUKER DALTONICS, Massachusetts, USA).

\section{Polymerase chain reaction $(\mathrm{PCR})$}

For DNA isolation, Staphylococcus spp. were originally cultured on Petri dishes with Columbia blood agar (OXOID, Hampsire, UK). This was followed by reproduction in BHI liquid medium (OXOID, Hampsire, UK) at $37^{\circ} \mathrm{C}$. Bacterial genomic DNA was extracted using the NucleoSpin Microbial DNA kit (MACHEREY-NAGEL GmbH \& Co. KG, Duren, Germany).

Primers (Tab 1) synthesized in AMPLIA s.r.o (Bratislava, SR) were used for genus and species identification of individual staphylococcal species by PCR.

Table 1 Characteristics of the primers used in this study

\begin{tabular}{|c|c|c|c|c|c|c|}
\hline $\begin{array}{l}\text { Staphylococcus } \\
\text { species }\end{array}$ & Target gene & Primer pair & Sequence $\left(5^{\prime} \rightarrow 3^{\prime}\right)$ & $\begin{array}{c}\text { annealing } \\
\text { temp. } \\
\left({ }^{\circ} \mathrm{C}\right)\end{array}$ & $\begin{array}{l}\text { Amplicon } \\
\text { size (bp) }\end{array}$ & $\begin{array}{l}\text { GenBank accession no. } \\
\text { (reference) }\end{array}$ \\
\hline $\begin{array}{l}\text { Ubiquitous } \\
\text { (Staphylococcus) }\end{array}$ & $16 \mathrm{~S}$ rDNA & $\begin{array}{l}16 \mathrm{~s} 1 \\
16 \mathrm{~s} 2\end{array}$ & $\begin{array}{l}\text { CAGCTCGTGTCGTGAGATGT } \\
\text { AATCATTTGTCCCACCTTCG }\end{array}$ & 55 & 420 & $\begin{array}{l}\text { Y15856 } \\
\text { al., 2001) }\end{array}$ \\
\hline S. aureus & $\begin{array}{l}\text { S. aureus- } \\
\text { specific sequence }\end{array}$ & $\begin{array}{l}\text { sau1 } \\
\text { sau2 }\end{array}$ & $\begin{array}{l}\text { AATCTTTGTCGGTACACGATATTCTTCACG } \\
\text { CGTAATGAGATTTCAGTAGATAATACAACA }\end{array}$ & 55 & 107 & $\begin{array}{l}\text { AF033191 (Martineau } \\
\text { et al., 1996) }\end{array}$ \\
\hline S. epidermidis & serp0107 gene & $\begin{array}{l}\text { Serp0107F } \\
\text { Serp0107R }\end{array}$ & $\begin{array}{l}\text { TTGAGCTTGTCATTGGTTCG } \\
\text { TGTAGAGGTTGCACGTCGAG }\end{array}$ & 55 & 581 & $\begin{array}{l}\text { CP000029 (Liu } \text { et al., } \\
\text { 2006) }\end{array}$ \\
\hline S. capitis & sodA gene & $\begin{array}{l}\text { ScapF } \\
\text { ScapR }\end{array}$ & $\begin{array}{l}\text { GCTAATTTAGATAGCGTACCTTCA } \\
\text { CAGATCCAAAGCGTGCA }\end{array}$ & 59 & 208 & $\begin{array}{l}\text { AJ343896 (Iwase } \text { et al., } \\
\text { 2007) }\end{array}$ \\
\hline S. haemolyticus & sodA gene & $\begin{array}{l}\text { ShaeF } \\
\text { ShaeR }\end{array}$ & $\begin{array}{l}\text { GTTGAGGGAACAGAT } \\
\text { CAGCTGTTTGAATATCTT }\end{array}$ & 50 & 85 & $\begin{array}{l}\text { AJ343910 (Iwase } \text { et al. } \\
\text { 2007) }\end{array}$ \\
\hline S. warneri & sodA gene & $\begin{array}{l}\text { SwarF } \\
\text { SwarR }\end{array}$ & $\begin{array}{l}\text { TGTAGCTAACTTAGATAGTGTTCCTTCT } \\
\text { CCGCCACCGTTATTTCTT }\end{array}$ & 60 & 63 & (Iwase et al. \\
\hline
\end{tabular}

PCR reactions were performed in FIREPol $^{\circledR}$ MasterMix (AMPLIA s.r.o, Bratislava, SR). In a total volume of $20 \mu \mathrm{l}$ containing $5 \mathrm{ng} / \mu \mathrm{l}$ of template DNA and $10 \mathrm{pmol}$ of each of the primers. This mixture was heated to $95^{\circ} \mathrm{C}$ for 5 minutes during the initial denaturation. 30 amplification cycles were performed (denaturation $95^{\circ} \mathrm{C} / 30 \mathrm{~s}$, annealing of each primer is indicated in Table $1 / 30$ and extension $72^{\circ} \mathrm{C} / 2 \mathrm{~min}$ ) in thermocycler (TECHNE TC-512, London, UK) with final extension 7 minutes $/ 72{ }^{\circ} \mathrm{C}$.

\section{Detection of Amplified DNA}

A $5 \mu \mathrm{l}$ portion of the amplified PCR product was analyzed on a $2 \%$ TBE agarose gel containing GelRed ${ }^{\mathrm{TM}}$ (Biotium, California, USA) at $120 \mathrm{~V}$ for 1 hour or until the desired resolution was achieved. Gels were monitored by UV transillumination (Mini Bis Pro ${ }^{\circledR}$, DNR BIO- IMAGING SYSTEMS Ltd., Jerusalem, Israel) and photographed using a $35 \mathrm{~mm}$ camera. Ladders of $100 \mathrm{bp}$ (AMPLIA s.ro, Bratislava, SK) were used as molecular size markers in all gels. PCR products were sequenced at the European Sequencing Center, GATC Biotech AG (Cologne, Germany). Subsequently, the obtained sequences were compared with the corresponding nucleotide sequences from the reference strains (accession no. GenBank in Tab 1). S. aureus CCM 4223, S. haemolyticus CCM 2737, S. epidermidis CCM 2124, S. capitis CCM 2734, S. warneri CCM 2730
(CZECH COLLECTION OF MICROORGANISMS, Brno, Czech Republic) served as positive controls in this study.

\section{RESULTS}

Our study confirmed the presence of Staphylococcus spp, from samples of fish meat, wild rabbit, wild pheasant, chickens and also bryndza cheese, by culture microbiological examination, on the basis of which 193 isolates were isolated. Specifically, in this study, 28 staphylococcal strains were isolated from alaska pollock samples, 21 staphylococcal strains isolated from Atlantic mackerel, 28 strains isolated from Atlantic herring, 29 staphylococcal strains from wild pheasants, 25 strains isolated from wild rabbit, 31 strains isolated from chicken and 31 staphylococal strains from bryndza cheese.

The obtained isolates were phenotypically and genotypically identified. When culturing individual isolates, their phenotypic features such as pigment formation, hemolysis, coagulase, deoxyribonuclease and susceptibility to the antibiotic novobiocin were evaluated. These features are characteristic of each type of CoNS. Staphylococcal plasma-coagulase activity was determined using a tube coagulase assay (TCA). Based on the TCA results, $170(88 \%)$ isolates were included in the group of coagulase-negative staphylococci and $23(12 \%)$ in the group of coagulase-positive strains ( $\mathrm{Tab} 2$ ). Of the total number of 23 coagulasepositive staphylococci, the formation of $\alpha$-hemolysis was detected in 4 strains (17 
$\%)$ and the formation of $\beta$-hemolysis in 19 strains (83\%). Of the 170 coagulasenegative staphylococci, 54 isolates (32\%) developed hemolysis.

Yellow pigment formation was confirmed in 23 coagulase-positive isolates $(100 \%)$ and in $18(11 \%)$ CoNS isolates. Nuclease production was also confirmed in isolates in 15 coagulase-positive staphylococcal (CoPS) isolates and in 6 CoNS isolates, where subsequent identification by MALDI-TOF-MS and PCR assay were nuclase-producing isolates assigned to $S$. aureus (15 isolates), $S$ warneri (4 zolates) and $S$. epidermidis (2 isolates).

Table 2 Overview of phenotypic properties of individual species of staphylococcal isolates

\begin{tabular}{lccccc}
\hline \multirow{2}{*}{ Species } & \multicolumn{3}{c}{ Hemolysis } & \multirow{2}{*}{ Pigment } & \multirow{2}{*}{ Nuclease } \\
\cline { 2 - 4 } & $\boldsymbol{\alpha}$ & $\boldsymbol{\beta}$ & without & & \\
\hline S. warneri & 43 & - & 52 & 12 & 4 \\
S. epidermidis & 6 & - & 58 & - & 2 \\
S. aureus & 4 & 19 & - & 23 & 15 \\
S. haemolyticus & 5 & - & 3 & 6 & - \\
S. capitis & - & - & 3 & - & - \\
\hline
\end{tabular}

The phenotypic features were originally classified by individual staphylococca isolates into the CoPS and CoNS groups. Based on the results of the disk diffusion method, CoNS were classified into the group of novobiocin-sensitive staphylococci, where the sizes of the inhibition zones ranged from $25 \mathrm{~mm}$ to 32 $\mathrm{mm}$. CoPS have been identified by phenotypic expression as the species of $S$. aureus that is most important for human pathogenicity.
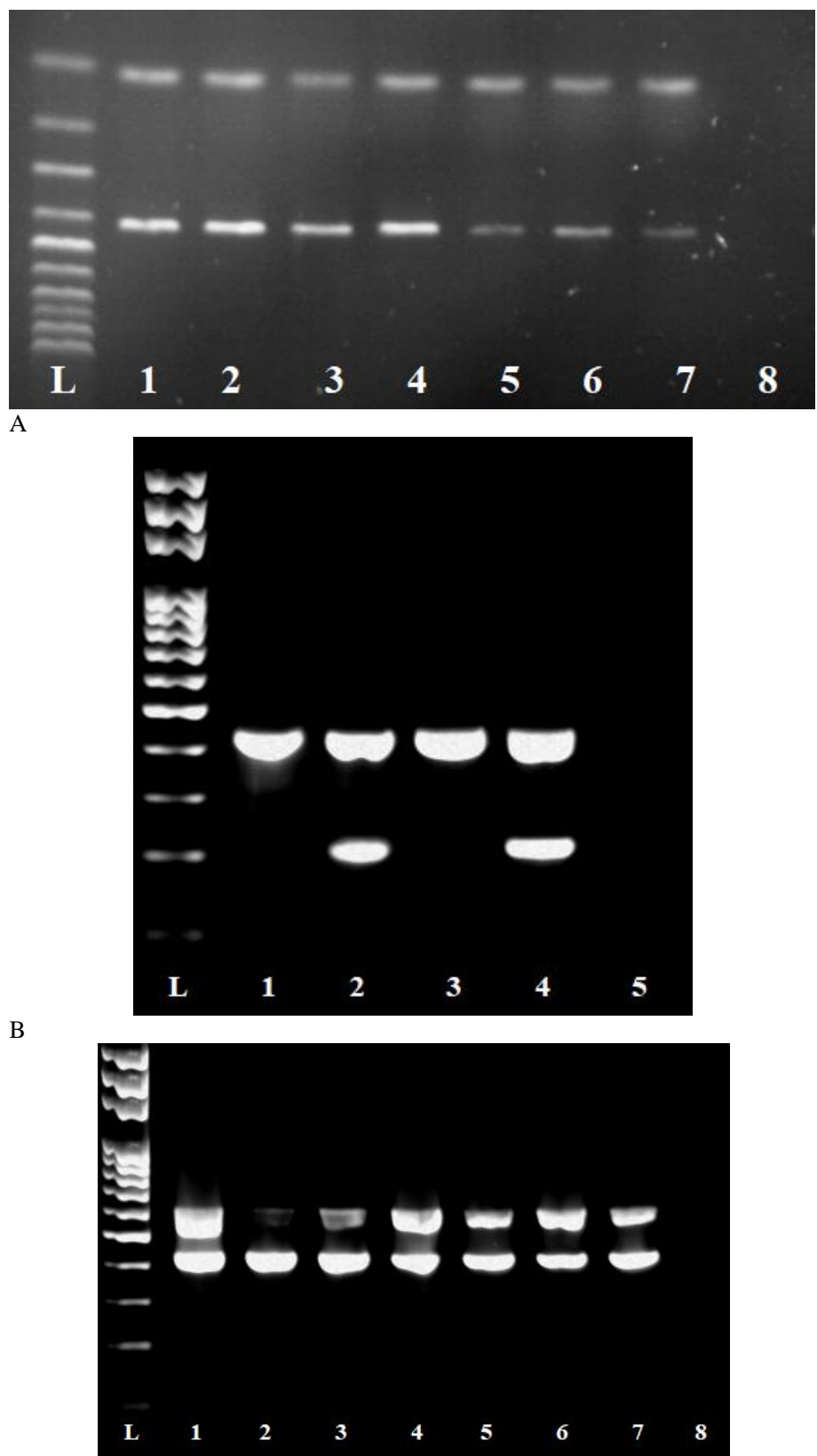
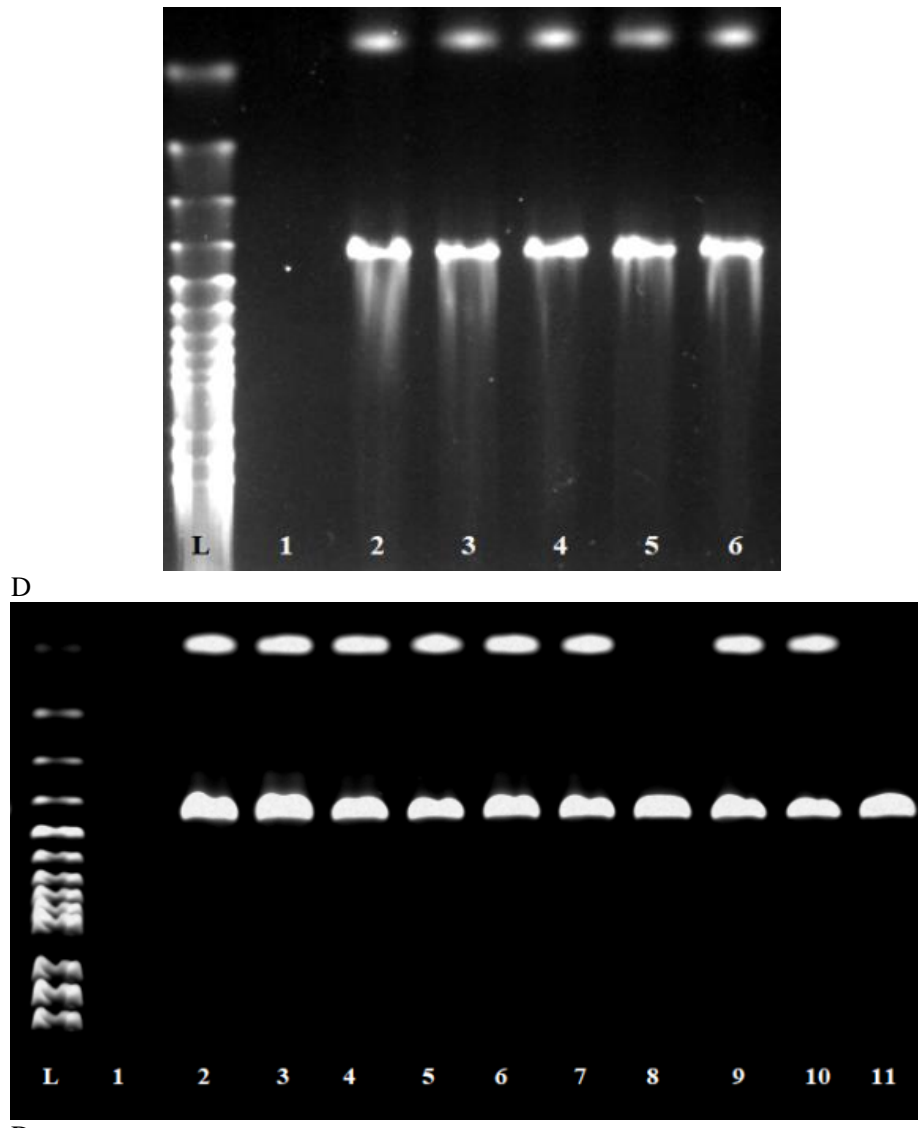

Figure 1 Identification of S.aureus (A), S. capitis (B), S. epidermidis (C), S. haemolyticus (D) and $S$. warneri (E) by PCR method.

Figure A: L - 100 bp ladder; Line 1 - reference strain S. aureus CCM 4223; Lines 2,3,4,5,6,7 - isolates of $S$. aureus. (107 bp - S. aureus-specific sequence; 420 bp - $16 S$ rDNA); Line 8 - negative control.

Figure B: L - 100 bp ladder; Lines 1,3 - unidentified isolates; Line 2 - isolates of S. capitis (208 bp - S. capitis-specific sequence; 420 bp - 16S rDNA); Line 4 reference strain S. capitis CCM 2734; Line 8 - negative control.

Figure C: L - 100 bp ladder; Lines 1,3,4,5,6 - isolates of S. epidermidis (587 bp S.epidermidis-specific sequence; $420 \mathrm{bp}-16 S \mathrm{rDNA}$ ); Line 2 - unidentified isolates; Line 7 - reference strain S. epidermidis CCM 2124; Line 8 - negative control.

Figure D: L - 100 bp ladder; Line 1 - negative control; Line 2 - reference strain S. haemolyticus CCM 2737; Lines 3,4,5,6 - isolates of S. haemolyticus (63 bp - S. haemolyticus-specific sequence; $420 \mathrm{bp}-16 \mathrm{~S}$ rDNA).

Figure E: L - 100 bp ladder; Line 1 - negative control; Line 2 - reference strain S. warneri CCM 2730; Lines 3,4,5,6,7,9,10 - isolates of S. warneri (85 bp- $S$ warneri-specific sequence; 420 bp - $16 S$ rDNA); Lines 8,11 - unidentified isolates.

After evaluation of all observed phenotypic manifestations, the isolates were subjected to further species identification by PCR method. The $16 \mathrm{~S} r D N A$ gene, housekeeping gene, has been used in the past for species identification of staphylococci. However, the 16S rDNA gene of Staphylococcus epidermidis is very similar to the gene in other CoNSs. Therefore, alternative target sequences were used, namely $S$. aureus specific sequences, S. epidermidis putative transcriptional regulator gene serp0107 and the specific sequence of the sodA gene (Fig 1) was used to identify S. warneri, S. haemolyticus, S. capitis.

The phenotypic manifestations of the isolates correlated with species identification using the PCR method. Five species of staphylococci were identified by PCR and subsequently by MALDI-TOF-MS, namely: $S$. aureus, $S$. epidermidis. S. capitis, S. haemolyticus, S. warneri.

When comparing the results of identification by PCR and MALDI-TOF-MS, the identification at the genus level was identical in all cases (100\%). However, discrepancies in the results were confirmed at the species level, where the congruence in the identification of isolates by PCR and MALDI-TOF-MS was only $80 \%$. For the mentioned isolates, the score value ranged from 1.953 to 2.564 (Tab 3). 
Table 3 Identification of staphylococcal isolates by MALDI-TOF-MS

\begin{tabular}{lcc}
\hline MALDI-TOF-MS Identification & $\mathbf{n}$ & Score value \\
\hline S. aureus & 23 & $1.705-2.325$ \\
S. warneri & 95 & $1.700-2.564$ \\
S. epidermidis & 64 & $1.700-2.545$ \\
S.haemolyticus & 8 & $1.874-2.420$ \\
S. capitis & 3 & $1.721-2.501$ \\
\hline
\end{tabular}

The score value 2.000-2.300 indicated highly probable identification of the species, score value 1.7-1.999 indicated identification of the genus and probable identification of the species, and score value 1.699-0.000 not reliable identification (Chen et al., 2014; Deng et al., 2014; Cheng et al., 2015).

Eight isolates were identified as S. epidermidis by MALDI-TOF-MS, but the presence of a specific sequence of $S$. warneri species (score valus 1.700-1.895) was confirmed in these isolates by PCR. The other 7 isolates confirmed the specific sequence for $S$. haemolyticus species, but MALDI-TOF-MS identified these isolates as $S$. warneri (score value 1.705-1.892).

In another 24 isolates identified by MALDI-TOF-MS as S. aureus (4 isolates), S. epidermidis (12 isolates), $S$. warneri (5 isolates), S. haemolyticus (1 isolate) and $S$. capitis (2 isolates) only $16 S \mathrm{rDNA}$ sequence specific for the genus Staphylococcus spp. (Tab 3) was confirmed by PCR. In these cases, the score was less than 2 (1.700-1.874). However, the producer recommends using the score to determine species-level identification above 2.000 .

When comparing the effectivity of the PCR method and MALDI-TOF-MS in genus and species identification, the presence of staphylococci in all tested food samples of animal origin was simultaneously confirmed.

Table 4 Number of species-identified staphylococci in individual types of food of animal origin

\begin{tabular}{|c|c|c|c|c|c|c|}
\hline & methods & S. aureus & S. epidermidis & S. warneri & S.haemolyticus & S. capitis \\
\hline \multirow{2}{*}{$\Sigma$} & MALDI-TOF-MS & 23 & 64 & 95 & 8 & 3 \\
\hline & PCR & 17 & 44 & 83 & 7 & 1 \\
\hline \multirow{2}{*}{$\begin{array}{l}\text { Alaska } \\
\text { pollock }\end{array}$} & MALDI-TOF-MS & - & 10 & 18 & - & - \\
\hline & PCR & - & 8 & 12 & - & - \\
\hline \multirow{2}{*}{$\begin{array}{l}\text { Atlantic } \\
\text { mackerel }\end{array}$} & MALDI-TOF-MS & - & 5 & 16 & - & - \\
\hline & PCR & - & 3 & 15 & - & - \\
\hline \multirow{2}{*}{$\begin{array}{l}\text { Atlantic } \\
\text { herring }\end{array}$} & MALDI-TOF-MS & - & 8 & 15 & 3 & 2 \\
\hline & PCR & - & 5 & 13 & 3 & - \\
\hline \multirow{2}{*}{$\begin{array}{l}\text { Wild } \\
\text { pheasant }\end{array}$} & MALDI-TOF-MS & - & 11 & 16 & 2 & - \\
\hline & PCR & - & 8 & 15 & 2 & - \\
\hline \multirow{2}{*}{ Wild rabbit } & MALDI-TOF-MS & 2 & 10 & 13 & - & - \\
\hline & PCR & 2 & 6 & 12 & - & - \\
\hline \multirow{2}{*}{ Chicken } & MALDI-TOF-MS & - & 15 & 12 & 3 & 1 \\
\hline & PCR & - & 11 & 12 & 2 & 1 \\
\hline \multirow{2}{*}{$\begin{array}{l}\text { Bryndza } \\
\text { cheese }\end{array}$} & MALDI-TOF-MS & 21 & 5 & 5 & - & - \\
\hline & PCR & 15 & 3 & 4 & - & - \\
\hline
\end{tabular}

As follows from Table 4, the presence of coagulase-positive species S. aureus was confirmed to a lesser extent in wild rabbit samples and to a greater extent in bryndza cheese samples. Coagulase-negative species $S$. epidermidis was most common in chicken thigh muscle samples, despite inconsistencies in the species identification of this species by both methods. S. warneri was also identified in all food samples, but the smallest number was detected in bryndza cheese samples. S. haemolyticus was confirmed only in small numbers in samples of herring, pheasant and chickens. The lowest number of identified isolates belonged to the species $S$. capitis. Its presence was confirmed by MALDI-TOFMS in herring samples, but it was confirmed by PCR method only in a chicken thigh muscle sample (Tab 4).

\section{DISCUSSION}

The microflora of food is mainly influenced by hygiene in the food chain Improper handling of food during the production process increases the risk of contamination of the final product by microbes, including multi-resistant and/or enterotoxigenic staphylococci (Ferroni et al., 2010; Hammad et al., 2012). Therefore the detection of the presence of bacteria Staphylococcus spp. in food is very important. The presence of these bacteria is also confirmed by this study, where the presence of 170 isolates of coagulase-negative staphylococci and 23 isolates of coagulase-positive staphylococci was confirmed by microbiological examination of samples and tube coagulase test. Phenotypic features such as the formation of hemolysis and pigment, were further monitored in these isolates. Formation of coagulum and nuclease activity, which are important in distinguishing between pathogenic staphylococci and non-pathogenic resident flora, have also been studied (Pfaller and Herwaldt, 1988). Nuclease production in CoNS was also confirmed by Lambe et al. (1990), who reported that most strains of S. epidermidis, S. warneri and S. haemolyticus tested in their study produced nuclease. Similarly, Cunha et al. (2006) confirmed 117 nuclease activity in 9 S. epidermidis isolates and two $S$. haemolyticus isolates when 117 CoNS isolates were examined, but nuclease production was not confirmed in $S$. warneri isolates. In this study, nuclease production was confirmed in $15 \mathrm{CoPS}$ isolates and 6 CoNS isolates.

The phenotypic features of staphylococcal isolates initially classified individua staphylococcal isolates, into the CoPS and CoNS groups. Based on the results of the disk diffusion method, CoNS were classified into the group of novobiocinsensitive staphylococci. CoPS were identified by their phenotypic expression as the species of $S$. aureus, which is of the greatest importance for human pathogenicity. Recently, the importance of CoNS in terms of the development of serious infections, especially infections of nosocomial origin, has also increased. Strains causing nosocomial infections are more common than other CoNS strains which contain features considered as virulence factors (ability to form a biofilm, antimicrobial resistance). Accurate identification and typing of these strains is therefore important for clinical and epidemiological reasons (Chomoucká, 2009).

Therefore, in this study, after initial identification by phenotypic expression of the isolates, more accurate identification was performed by MALDI-TOF-MS and PCR. The phenotypic manifestations of the isolates correlated with species identification by PCR. Five species of staphylococci were identified by PCR and subsequently by MALDI-TOF-MS, namely: S. aureus, S. epidermidis. S. capitis, $S$. haemolyticus. S. warneri. Until recently, the $16 S$ rDNA gene, a housekeeping gene, was used for PCR identification, which is generally targeted when speciesspecific detection by PCR is performed. This is also confirmed by Sindhu $\boldsymbol{e t} \boldsymbol{a l}$. (2007) and Organji et al. (2018), who used sequence of $16 S$ rDNA gene as a target to identify staphylococcal isolates. However, the $16 \mathrm{~S} r D N A$ gene of $S$. epidermidis is very similar to the gene in other CoNSs. To solve this problem, alternative target sequences that show higher divergence than the $16 \mathrm{~S}$ rDNA gene have been used, namely the $S$. aureus specific sequence, the putative transcriptional regulator gene serp0107 and the sodA gene (Poyart et al., 2001) When comparing the results of identification by PCR and MALDI-TOF-MS, the identification at the genus level was identical in all cases (100\%). However, discrepancies in the results were confirmed at the species level, where the congruence in the identification of isolates by PCR and MALDI-TOF-MS was only $80 \%$. For the remaining $20 \%$, the identification between MALDI-TOF-MS and PCR did not match.

In the mentioned cases, the score was lower than 2.000 (1.700-1.874). Although the manufacturer recommends using scores to determine species-level identification above 2.000 , lower cut-off scores have been used in the past to identify individual Gram-positive cocci species (Deak et al., 2015). Also in the studies of Dubois et al. (2012), Kim et al. (2012) and Martiny et al. (2012) they confirmed lower species identification accuracy by MALDI-TOF-MS for CoNS isolates.

Based on work on the application of MALDI-TOF-MS on microorganisms, it was confirmed that the choice of the correct matrix is a very important factor in the correct identification of microorganisms. Staphylococci are HCCA and ferulic acid, which allows the detection of high molecular weight proteins up to $70 \mathrm{kDa}$ (Keys et al., 2004; Madonna et al., 2000). However, in order to obtain quality spectra, it is necessary to first disrupt the Gram-positive bacterial cell and thus release its proteins (Smole et al., 2002). When preparing their samples, it is 
therefore necessary to first disrupt the thick peptidoglycan layer, which does not allow the ionization of proteins that are protected by the cell wall or are attached to it. One of the proven methods to disrupt the peptidoglycan layer is the use of lysozyme or lysostaphin. In addition to enzymatic methods for disrupting the cell wall, physical methods and chemical methods using various solvents, such as ethanol, are used, which we have also used in this study. The nature of the spectrum is also affected by the correct crystallization on the plate and the ionization capabilities of the analyte. The intensity (height) of the signa corresponds to the relative protein concentration at the laser impact site and depends on the degree of ionization (Vaňousová, 2010). Staphylococcus spectra usually show 50-75 signals with a weight of $1.8 \mathrm{kDa}$ (Smole et al., 2002).

Identification of microorganisms is performed by comparing the obtained spectrum with a database of characteristic known spectra. A signal present in different spectra can be evaluated as a single protein if its size differs by a maximum of \pm 3 Da (Smole $\boldsymbol{e t}$ al., 2002). Spectrum analysis first searches for genus-specific signals common to all species. For example for the genus Staphylococcus it is the signal 9625 Da. Further, common intraspecific signals are searched. The identification and quantification of the signals of the examined spectrum is followed by the calculation of similarity with other mass spectra analyzed or obtained from the reference library (Vaňousová, 2010). Other factors that may affect the accuracy of the identification of Staphylococcus isolates by MALDI-TOF-MS are the composition of the culture medium and the duration of the culture, as confirmed by the study by Šedo et al. (2013) on bacterial strains isolated from food, where a more accurate species distinction was achieved by changing the culture conditions.

This was similarly confirmed by Prod'hom et al.(2010), who used blood culture to propagate staphylococci to identify bacteria by MALDI-TOF-MS, leading to the correct identification of $79 \%$ of the isolates tested at the species level. More specifically, all 25 cases of $S$. aureus bacteremia were identified, but scored only 1.7, indicating an identification that is only reliable at the genus level. Other groups have also confirmed the high efficiency of $S$. aureus identification in blood cultures at the genus level only using MALDI-TOF-MS (Christner $\boldsymbol{e t}$ al. 2010; Ferroni et al., 2010; Stevenson et al., 2010). Clerc et al. (2014) also identified $S$. aureus by MALDI-TOF-MS. In the study, $5.5 \%$ of S. aureus isolates were identified incorrectly. All showed scores <1.7; therefore, the species has not been correctly identified at the species level.

Manukumar and Umesha (2017) confirmed the presence of staphylococca species in food samples. They identified by MALDI-TOF-MS, a species of $S$ aureus where $94 \%$ of the isolates tested had a score higher than 2.000 , a species of $S$. epidermidis where a score higher than 2,000 showed $83.3 \%$ of isolates and a species of $S$. haemolyticus where a score higher than 2.000 showed $100 \%$. These results correlate with our study, where the smallest differences in identification were in the species $S$. haemolyticus. This staphylococcal species as well as $S$. epidermidis and $S$. warneri were confirmed by Kačániová et al., 2019 by MALDI-TOF-MS in samples of Slovak cheese "Parenica". However, it also notes that while MALDI-TOF-MS has revolutionized speed and precision of microbial identification for clinical isolates, in contrast few performance studies have been published so far focusing on suitability for particularly industrial applications.

In addition to CoNS (Tvarožková et al., 2020), the species $S$. aureus (Zigo et al. 2011; Tančin et al. 2017; Holko et al. 2018) is often identified in milk and dairy products, similarly to our study where in bryndza its presence was confirmed by both methods.

Like the above-mentioned studies, Pipová et al. (2012), Chan et al. (2014) and Regecová et al. (2014) also confirmed that MALDI-TOF-MS can be used as a complementary screening method in the identification of individual staphylococcal species. These claims are also supported by Gekenidis et al (2014), who proves that MALDI-TOF-MS has certain restrictions. First of all, unlike sequence databases such as GenBank, MALDI-TOF-MS databases are no publicly available. The low percentage of identification of some organisms can be improved by the addition of mass spectral records of under-represented species or strains. Due to the low score/percentage, retesting may be required. Growth on some media can also negatively affect scores/percentages. Identification of small or mucoid colonies can be a problem in the accurate identification of isolates by MALDI-TOF MS. Small colonies can be identified more quickly by gene sequencing than by MALDI-TOF-MS.

Low identification scores are also affected by laboratory errors that can occur when applying colonies to the diagnostic plate. Although MALDI-TOF-MS is generally reproducible, there are sources of variability, including mass spectrometry, matrix and solvent composition, methods of preparation, training and technologist competence, culture conditions (such as media, colony-age, temperature) and biological variability (Patel, 2015)

\section{CONCLUSION}

The study confirmed the presence of staphylococci in food samples. A total of 193 isolates were tested, which were classified as $S$. aureus, S. epidermidis, $S$ capitis, $S$. haemolyticus, $S$. warneri on the basis of phenotypic expression and identification by MALDI-TOF-MS and PCR. In the identification of MALDITOF-MS and PCR method, there were discrepancies in the identification of staphylococcal species in $20 \%$ of the tested isolates. Therefore, we can conclude that MALDI-TOF mass spectrometry is a suitable and quick method for the identification of food isolates of staphylococci at the genus level.

However, further studies are needed to standardize culture procedures, sample preparation of bacterial cultures, as well as procedures for the handling of prepared samples before testing by MALDI-TOF-MS, which affect the accuracy and resulting success scores for food staphylococcal isolates, especially at the species level. Our results point to MALDI-TOF-MS as a rapid method for the identification of staphylococci, which, however, requires verification by PCR

Acknowledgement: This work was supported by IGA UVLF 01/2017 and Scientific Grant Agency of the Ministry of Education, Science, Research and Sport of the Slovak Republic and the Slovak Academy of Sciences (VEGA $1 / 0705 / 16$ )

\section{REFERENCES}

Becton Dickinson \& Comp. (1996). Zone Diameter Interpretive Chart. Technical Information. Cockeysville, MD, USA.

Bencúrová, E., Bhide, M., Dolinská, S., Hreško, S., Mlynárčik, P., Mucha, R. \& Pulzová, L. (2013). Nové trendy vo využivani bioinformatických analýz $v$ genomike a proteomike. Košice: University of Veterinary Medicine and Pharmacy in Košice.

Bruker Daltonics, MALDI Biotyper 2.0. (2008). Software for microorganism identification and classification user manual. United Kingdom.

Chan, W. S., Chan, T. M., Lai, T. W., Chan, J. F. W., Lai, R. W. M., Lai, Ch. K. Ch., \& Tang., B. S. F. (2014). Complementary use of MALDI-TOF MS and Real-Time PCR-melt curve analysis for rapid identification of methicillinresistant staphylococci and VRE. Journal of Antimicrobial Chemotherapy, 70(2), 441-447. http://dx.doi.org/10.1093/jac/dku411

Chen, P. L., Lee, T. F., Wu, C. J., Teng, S. H., Teng, L. J., Ko, W. C., \& Hsueh, P. R. (2014). Matrix-assisted laser desorption ionization-time of flight mass spectrometry can accurately differentiate Aeromonas dhakensis from $A$ hydrophila, A. caviae, and A. veronii. Journal of Clinical Microbiology, 52(7), 2625-2628. http://dx.doi.org/10.1128/JCM.01025-14

Cheng, W. C., Jan, I. S., Chen, J. M., Teng, S. H., Teng, L. J., Sheng, W. H., .. Hsueh, P. R. (2015). Evaluation of the bruker biotyper matrix-assisted laser desorption ionization-time of flight mass spectrometry system for identification of blood isolates of Vibrio species. Journal of Clinical Microbiology, 53(5), 1741-1744. http://dx.doi.org/10.1128/jcm.00105-15

Chomoucká, J. (2009). Typing of phenotypicaly difficult distinguishable isolates of coagulase-negative staphylococci. Masaryk University of Brno, Czech Republic: https://is.muni.cz/th/g0xq7/diplomova prace.pdf.

Christner, M., Rohde, H., Wolters, M., Sobottka, I., Wegscheider, K., \& Aepfelbacher, M. (2010). Rapid Identification of bacteria from positive blood culture bottles by use of matrix-assisted laser desorption-ionization time of flight mass spectrometry fingerprinting. Journal of Clinical Microbiology, 48(5), 15841591. http://dx.doi.org/10.1128/jcm.01831-09

Clark, A. E., Kaleta, E. J., Arora, A., \& Wolk, D. M. (2013). Matrix-Assisted Laser Desorption Ionization-Time of Flight Mass Spectrometry: a fundamental shift in the routine practice of clinical microbiology. Clinical Microbiology Reviews, 26(3), 547-603. http://dx.doi.org/10.1128/cmr.00072-12

Clerc, O., Prod'hom, G., Senn, L., Jaton, K., Zanetti, G., Calandra, T., \& Greub, G. (2014). Matrix-assisted laser desorption ionization time-of-flight mass spectrometry and PCR-based rapid diagnosis of Staphylococcus aureus bacteraemia. Clinical Microbiology and Infection, 20(4), 355-360 http://dx.doi.org/10.1111/1469-0691.12329

Corbière Morot-Bizot, S., Leroy, S., \& Talon, R. (2007). Monitoring of staphylococcal starters in two French processing plants manufacturing dry fermented sausages. Journal of Applied Microbiology, 102(1), 238-244 http://dx.doi.org/10.1111/j.1365-2672.2006.03041.x

Croxatto, A., Prod'hom, G., \& Greub, G. (2012). Applications of MALDI-TOF mass spectrometry in clinical diagnostic microbiology. FEMS Microbiology Reviews, 36(2), 380-407. http://dx.doi.org/10.1111/j.1574-6976.2011.00298.x

Cunha, M. de L. R. de S. da, Rugolo, L. M. S. de S., \& Lopes, C. A. de M. (2006). Study of virulence factors in coagulase-negative staphylococci isolated from newborns. Memórias Do Instituto Oswaldo Cruz, 101(6), 661-668. http://dx.doi.org/10.1590/s0074-02762006000600014

Deak, E., Charlton, C. L., Bobenchik, A. M., Miller, S. A., Pollett, S., McHardy, I. H., ... Garner, O. B. (2015). Comparison of the Vitek MS and Bruker Microflex LT MALDI-TOF MS platforms for routine identification of commonly isolated bacteria and yeast in the clinical microbiology laboratory. Diagnostic $\begin{array}{llll}\text { Microbiology and Infectious } & \text { Disease, 27-33. }\end{array}$ http://dx.doi.org/10.1016/j.diagmicrobio.2014.09.018

Deng, J., Fu, L., Wang, R., Yu, N., Ding, X., Jiang, L., ... Che, X. (2014). Comparison of MALDI-TOF MS, gene sequencing and the Vitek 2 for identification of seventy-three clinical isolates of enteropathogens. Journal of Thoracic Disease, 6(5), 539-544. http://dx.doi.org/10.3978/i.issn.2072 $\underline{1439.2014 .02 .20}$ 
Drozenová, J, Petráš, P. (2000). Vlastnosti koaguláza-negativních stafylokoků izolovaných z hemokultur. Epidemiologie, Mikrobioligie, Imunoogie, 49(2), 5158. 2.html?clanek $=4909 \&$ jazyk $=1 \&$ cislo $=262$

Dubois, D., Grare, M., Prere, M.-F., Segonds, C., Marty, N., \& Oswald, E. (2012). Performances of the Vitek MS matrix-assisted laser desorption ionization-time of flight mass spectrometry system for rapid identification of bacteria in routine clinical microbiology. Journal of Clinical Microbiology, 50(8), 2568-2576. http://dx.doi.org/10.1128/jcm.00343-12

Dunman, P. M., Murphy, E., Haney, S., Palacios, D., Tucker-Kellogg, G., Wu, S., ... Projan, S. J. (2001). Transcription profiling-based identification of staphylococcus aureus genes regulated by the agrand/or sarA loci. Journal of Bacteriology, 183(24), 7341-7353. http://dx.doi.org/10.1128/jb.183.24.7341 7353.2001

Ferroni, A., Suarez, S., Beretti, J. L., Dauphin, B., Bille, E., Meyer, J., ... Nassif, X. (2010). Real-Time identification of bacteria and Candida species in positive blood culture broths by matrix-assisted laser desorption ionization-time of flight mass spectrometry. Journal of Clinical Microbiology, 48(5), 1542-1548. http://dx.doi.org/10.1128/jcm.02485-09

Gekenidis, M. T., Studer, P., Wüthrich, S., Brunisholz, R., \& Drissner, D. (2014). Beyond the matrix-assisted laser desorption ionization (MALDI) biotyping workflow: in search of microorganism-specific tryptic peptides enabling discrimination of subspecies. Applied and Environmental Microbiology, 80(14), 4234-4241. http://dx.doi.org/10.1128/aem.00740-14

Hammad, A. M., Watanabe, W., Fujii, T., \& Shimamoto, T. (2012). Occurrence and characteristics of methicillin-resistant and -susceptible Staphylococcus aureus and methicillin-resistant coagulase-negative staphylococci from Japanese retail ready-to-eat raw fish. International Journal of Food Microbiology, 156(3), 286-289. http://dx.doi.org/10.1016/j.ijfoodmicro.2012.03.022

Holko, I., Tančin, V., Tvarožková, K., Supuka, P., Supuková, A. (2018). Udder Pathogens Isolated from Sheep Milk in Slovakia. XLVIII. Lenfeldovy a Höklovy dny. Brno: Veterinární a farmaceutická univerzita, p. 169-172. ISBN 978-807305-808-1.

Iacumin, L., Comi, G., Cantoni, C., \& Cocolin, L. (2006). Ecology and dynamics of coagulase-negative cocci isolated from naturally fermented Italian sausages Systematic and Applied Microbiology, 29(6), 480-486. http://dx.doi.org/10.1016/j.syapm.2005.11.006

International Organization for Standardization. (2003). Microbiology of food and animal feeding stuffs. Horizontal method for the enumeration of coagulasepositive staphylococci (Staphylococcus aureus and other species). Part 1: Technique using Baird-Parker agar medium. ISO 6888-1/A1-2003. ISO, Geneva, Switzerland: https://www.iso.org/standard/76672.html.

International Organization for Standardization. (2020). Microbiology of food and animal feeding stuffs.Preparation of test samples, initial suspension and decimal dilutions for microbiological examination. Part 5:Specific rules for the preparation of milk and milk products. ISO 6887-5-2020. ISO, Geneva, Switzerland: https://www.iso.org/standard/71502.html.

International Organization for Standardization. (2017). Microbiology of food and animal feeding stuffs. Preparation of test samples, initial suspension and decima dilutions for microbiological examination. Part 3: Specific rules for the preparation of fish and fishery products. ISO 6887-3-2017. ISO, Geneva, Switzerland: https://www.iso.org/standard/77420.html

International Organization for Standardization. (2017). Microbiology of the food chain - Preparation of test samples, initial suspension and decimal dilutions for microbiological examination. Part 2: Specific rules for the preparation of meat and meat products. ISO 6887-2-2017. ISO, Geneva, Switzerland: https://www.iso.org/standard/63336.html.

Irlinger, F. (2008). Safety assessment of dairy microorganisms: Coagulasenegative staphylococci. International Journal of Food Microbiology, 126(3), 302-310. http://dx.doi.org/10.1016/j.ijfoodmicro.2007.08.016

Iwase, T., Seki, K., Shinji, H., Mizunoe, Y., \& Masuda, S. (2007). Development of a real-time PCR assay for the detection and identification of Staphylococcus capitis, Staphylococcus haemolyticus and Staphylococcus warneri. Journal of Medical Microbiology, 56(10),

1346-1349. http://dx.doi.org/10.1099/jmm.0.47235-0

Kačániová, M., Kunová, S., Nagyová, L., Horská, E., Haščík, P., \& Terentjeva, M. (2019). Application of MALDI-TOF mass spectrometry for identification of bacteria isolated from traditional Slovak cheese "Parenica." Journal of Microbiology, Biotechnology and Food Sciences, 8(6), 1294-1297. http://dx.doi.org/10.15414/jmbfs.2019.8.6.1294-1297

Keys, C. J., Dare, D. J., Sutton, H., Wells, G., Lunt, M., McKenna, T., ... Shah, H. N. (2004). Compilation of a MALDI-TOF mass spectral database for the rapid screening and characterisation of bacteria implicated in human infectious diseases. Infection, Genetics and Evolution, 4(3), 221-242. http://dx.doi.org/10.1016/j.meegid.2004.02.004

Kim, M., Kwon, M. J., Chung, H.-S., Lee, Y., Yong, D., Jeong, S. H., ... Chong, Y. (2012). Evaluation of matrix-assisted laser desorption ionization-time of fligh mass spectrometry for identification of aerobic bacteria in a clinical microbiology laboratory. Korean Journal of Clinical Microbiology, 15(2), 60. http://dx.doi.org/10.5145/kjcm.2012.15.2.60
Lambe Jr., D. W., Ferguson, K. P., Keplinger, J. L., Gemmell, C. G., \& Kalbfleisch, J. H. (1990). Pathogenicity of Staphylococcus lugdunensis, Staphylococcus schleiferi, and three other coagulase-negative staphylococci in a mouse model and possible virulence factors. Canadian Journal of Microbiology, 36(7), 455-463. http://dx.doi.org/10.1139/m90-080

Liu, D., Swiatlo, E., Austin, F. W., \& Lawrence, M. L. (2006). Use of a putative transcriptional regulator gene as target for specific identification of Staphylococcus epidermidis. Letters in Applied Microbiology, 43(3), 325-330. http://dx.doi.org/10.1111/j.1472-765x.2006.01948.x

Madonna, A. J., Basile, F., Ferrer, I., Meetani, M. A., Rees, J. C., Voorhes, K. J. (2000). On-probe sample pretreatment for the detection of proteins above $15 \mathrm{kDa}$ from whole cell bacteria by matrix-assisted laser desorption/ionization time-offlight mass spectrometry. Rapid Communications in Mass Spectrometry, 14 (23), 2220-2229. http://dx.doi.org/10.1002/1097-0231(20001215)14:23<2220::AIDRCM155>3.0.CO;2-4

Manukumar, H. M., \& Umesha, S. (2017). MALDI-TOF-MS based identification and molecular characterization of food associated methicillin-resistan Staphylococcus aureus. Scientific Reports, http://dx.doi.org/10.1038/s41598-017-11597-Z

Martineau, F., Picard, F. J., Roy, P. H., Ouellette, M., \& Bergeron, M. G. (1996). Species-specific and ubiquitous DNA-based assays for rapid identification of Staphylococcus epidermidis. Journal of Clinical Microbiology, 34(12), 28882893. http://dx.doi.org/10.1128/jcm.34.12.2888-2893.1996

Martiny, D., Busson, L., Wybo, I., El Haj, R. A., Dediste, A., \& Vandenberg, O. (2012). Comparison of the Microflex LT and Vitek MS systems for routine identification of bacteria by matrix-assisted laser desorption ionization-time of flight mass spectrometry. Journal of Clinical Microbiology, 50(4), 1313-1325. http://dx.doi.org/10.1128/jcm.05971-11

Martín, B., Garriga, M., Hugas, M., Bover-Cid, S., Veciana-Nogués, M. T., \& Aymerich, T. (2006). Molecular, technological and safety characterization of Gram-positive catalase-positive cocci from slightly fermented sausages International Journal of Food Microbiology, 107(2), 148-158. http://dx.doi.org/10.1016/j.ijfoodmicro.2005.08.024

Organji, S. R., Abulreesh, H. H., Elbanna, K., Osman, G. E. H., \& Almalki, M. H. K. (2018). Diversity and characterization of Staphylococcus spp. in food and dairy products: a foodstuff safety assessment. Journal of Microbiology, Biotechnology and Food Sciences, 7(6), 586-593. http://dx.doi.org/10.15414/jmbfs.2018.7.6.586-593

Patel, R. (2015). MALDI-TOF MS for the diagnosis of infectious diseases $\begin{array}{lll}\text { Clinical Chemistry, 61(1), 100-111. } & \text { C }\end{array}$ http://dx.doi.org/10.1373/clinchem.2014.221770

Pfaller, M., Herwaldt, L. A. (1988). Laboratory, Clinical, and Epidemiological Aspects of Coagulase-Negative Staphylococci. Clinical Microbiology Reviews, 3(1), 281-299. http://dx.doi.org/10.1128/CMR.1.3.281

Pipová, M., Jevinová, P., Kmet', V., Regecová, I., Marušková, K. (2012). Antimicrobial resistance and species identification of staphylococci isolated from the meat of wild rabbits (Oryctolagus cuniculus) in Slovakia. European journal of wildlife research, 58(1), 157-165. http://dx.doi.org/10.1007/s10344-011-05582

Pesavento, G., Calonico, C., Ducci, B., Magnanini, A., \& Lo Nostro, A. (2014). Prevalence and antibiotic resistance of Enterococcus spp. isolated from retai cheese, ready-to-eat salads, ham, and raw meat. Food Microbiology, 41, 1-7. http://dx.doi.org/10.1016/j.fm.2014.01.008

Poyart, C., Quesne, G., Boumaila, C., \& Trieu-Cuot, P. (2001). Rapid and accurate species-level identification of coagulase-negative staphylococci by using the sodA gene as a target. Journal of Clinical Microbiology, 39(12), 4296-4301 http://dx.doi.org/10.1128/jcm.39.12.4296-4301.2001

Prod'hom, G., Bizzini, A., Durussel, C., Bille, J., \& Greub, G. (2010). Matrixassisted laser desorption ionization-time of flight mass spectrometry for direct bacterial identification from positive blood culture pellets. Journal of Clinical Microbiology, 48(4), 1481-1483. http://dx.doi.org/10.1128/jcm.01780-09

Regecová, I., Pipová, M., Jevinová, P., Kmet’, V., Výrostková, J., \& Sopková, D. (2014). Antimicrobial resistance of coagulase-negative species of staphylococci isolated from the meat of wild pheasants (Phasianus colchicus). Italian Journal of Animal Science, 13(3), 3476. http://dx.doi.org/10.4081/ijas.2014.3476

Silva, N. C. C. (2017). Biofilm production by Staphylococcus sp. on stainless steel chips in contact with Brazilian minas cheese homogenates and BHI broth under different extrinsic factors. Journal of Microbiology, Biotechnology and Food Sciences, 7(2), 190-192. http://dx.doi.org/10.15414/jmbfs.2017.7.2.190192

Sindhu, N., Sharma, A., Kumar, S., \& Jain, V. K. (2007). Polymerase chain reaction assay for detection of Staphylococcus aureus in buffalo milk. Italian Journal of Animal Science, 6(sup2), 862-864. http://dx.doi.org/10.4081/ijas.2007.s2.862

Smole, S. C., King, L. A., Leopold, P. E., \& Arbeit, R. D. (2002). Sample preparation of Gram-positive bacteria for identification by matrix assisted laser desorption/ionization time-of-flight. Journal of Microbiological Methods, 48(2 3), 107-115. http://dx.doi.org/10.1016/s0167-7012(01)00315-3

Stevenson, L. G., Drake, S. K., \& Murray, P. R. (2009). Rapid identification of bacteria in positive blood culture broths by matrix-assisted laser desorption 
ionization-time of flight mass spectrometry. Journal of Clinical Microbiology, 48(2), 444-447. http://dx.doi.org/10.1128/jcm.01541-09

Stollberger, C., Wechslerfordos, A., Geppert, F., Gulz, W., Brownstone, E., Nicolakis, M., \& Finsterer, J. (2006). Staphylococcus warneri endocarditis after implantation of a lumbar disc prosthesis in an immunocompetent patient. Journal of Infection, 52(1), e15-e18. http://dx.doi.org/10.1016/j.jinf.2005.04.016

Šedo, O., Vávrová, A., Vad'urová, M., Tvrzová, L., \& Zdráhal, Z. (2013). The influence of growth conditions on strain differentiation within the Lactobacillus acidophilus group using matrix-assisted laser desorption/ionization time-of-fligh mass spectrometry profiling. Rapid Communications in Mass Spectrometry, 27(24), 2729-2736. http://dx.doi.org/10.1002/rcm.6741

Tančin, V., Holko, I., Vršková, M., Uhrinčat', M., Mačuhová, L. (2017). Relationship between presence of mastitis pathogens and somatic cell count in milk of ewes. XLVII. Lenfeldovy a Höklovy dny. Brno: Veterinární a farmaceutická univerzita, p. 230-233. ISBN 978-80-7305793-0.

Tvarožková, K., Tančin, V., Uhrinčat', M., Hleba, L., Mačuhová, L. (2020) Mastitis pathogens and somatic cell count in ewes milk. Potravinarstvo Slovak Journal of Food Sciences, 14, 2020, 164-169. https://dx.doi.org/10.5219/1338

Vaňousová, T. (2010). Characterization of selected staphylococcal species isolated from the environment. Masaryk University of Brno, Czech Republic: https://is.muni.cz/th/dvh4o/Diplomova_prace.pdf.

Von Eiff, C., Peters, G., \& Becker, K. (2006). The small colony variant (SCV) concept - the role of staphylococcal SCVs in persistent infections. Injury, 37(2), S26-S33. http://dx.doi.org/10.1016/j.injury.2006.04.006

Wenning, M., Breitenwieser, F., Konrad, R., Huber, I., Busch, U., \& Scherer, S. (2014). Identification and differentiation of food-related bacteria: A comparison of FTIR spectroscopy and MALDI-TOF mass spectrometry. Journal of Microbiological Methods, $\quad 103, \quad 44-52$ http://dx.doi.org/10.1016/j.mimet.2014.05.011

Zell, C., Resch, M., Rosenstein, R., Albrecht, T., Hertel, C., \& Götz, F. (2008) Characterization of toxin production of coagulase-negative staphylococci isolated from food and starter cultures. International Journal of Food Microbiology, 127(3), 246-251. http://dx.doi.org/10.1016/j.ijfoodmicro.2008.07.016

Zigo, F., Vasil', M., Kadáši, M., Elečko, J., Farkašová, Z. (2011). Bacteria Staphylococcus sp. izolated from mastitis of sheep and their enterotoxigenic properties. Potravinarstvo Slovak Journal of Food Sciences, 5 (4), 70-72. https://dx.doi.org/10.5219/171 